\title{
Hepatitis $B$ vaccination and immunization of dental students
}

\author{
Ana de Lourdes Sá de LIRA'; Keila Rejane de Jesus MARTINS² \\ 1 - PhD Teacher course of Dentistry, State University of Piauí, Parnaíba, PI, Brazil; 2 - Graduated course of Dentistry, State Univer-
} sity of Piauí, Parnaíba, PI, Brazil.

\begin{abstract}
Aim: to determine the previous prevalence of vaccination and immunity/serum conversion and after vaccination against hepatitis B in dental academics. Material and Methods: A study was carried out on 101 undergraduate dental students who were enrolled in 2017 and those who enrolled in the first half of 2018. The research consisted of two stages: the first one (T1) with a self-administered questionnaire with epidemiological data with a vaccination card check and by applying the test to confirm the immunization. The second one (T2) corresponding to vaccination non-seroconverted and never vaccinated in addition to the immunity test. Results: The age of the participants varied between 18 and 26 years (average of 21.5). Most were white (57.8\%), followed by brown (31.6\%) and black (8.4\%). Seventy-one students (70.3\%) entered the course due to wide competition and $30(29.7 \%)$ by quota system. it was verified that 97 participants (96\%) were immunized against HB, compared to $4(4 \%)$ that were not. This result was statistically significant $\left(\chi^{2}=85.63, \mathrm{p}<0.001\right)$. In the binomial probabilistic analysis of the risk factors studied, increasing age (OR: 1.08; 95\% CI: 1.02-1.14), history of blood transfusion (OR: 6.41; 95\% CI: 1.536 .83$)$, increasing in the number of periods of clinical activity during the course (OR: 1.71; 95\% CI: 1.02-2.92), and history of accident with biological material (OR: 6.82; 95\% CI: $1.59-7.15)$ were significantly associated with HBV infection in the studied populationConclusion: The prevalence of seroconversion was $96.03 \%$, corresponding to 97 immunized students. Although all dental academics completed the vaccination cycle (3 doses), 4 were not immunized. Vaccination and the need for serological testing (anti-HBs) for immunization verification should be encouraged to all dental students.
\end{abstract}

KEYWORDS: Hepatitis B. Immunization. Vaccination.

CORRESPONDING AUTHOR

Ana de Lourdes Sá de Lira

Universidade Estadual do Piauí, Faculdade de Odontologia

Rua Senador Joaquim Pires, 2076, Ininga.

CEP: 64049-590, Teresina-PI, Brasil

Phone: (55) 86 99959-5004 / E-mail: anadelourdessl@hotmail.com 


\section{Introduction}

Hepatitis B (HB) is a disease caused by the hepatitis B virus (HBV). It is transmissible through the percutaneous and parenteral routes, through accidents or sharing of contaminated objects, and through the sexual route. It is one of the main causes of morbidity and mortality in the world context, and its epidemiological data are of great concern to the main health centers, characterizing it as a public health problem ${ }^{1-3}$.

This virus is a recognized occupational hazard for dental practitioners and professionals. Percutaneous or mucosal exposures to the blood of infected individuals represent the main source of occupational transmission, since minute amounts of blood are sufficient to transmit the infection, with great environmental resistance, surviving for more than a week at room temperature ${ }^{4,5}$.

HBV is more easily transmitted after an accident involving body fluids and has a higher degree of infectivity than hepatitis $\mathrm{C}$ virus (HCV) and human immunodeficiency virus (HIV) $)^{6,7}$.

In Brazil, vaccination against $\mathrm{HB}$ is universally recommended for newborns, adolescents up to the age of 19, and persons at increased risk for acquiring the infection, among them dentistry professionals. Due to the characteristics of the dental practice involving work with sharp instruments and body fluids in a restricted field of vision, anti-HBs vaccination is a priority measure among infection control procedures ${ }^{8}$.

Blood and other body fluids from a person with HBV can be infectious two to three weeks before the first signs of the disease appear, and remain so during the acute phase. Special attention should be given to chronic carriers who may remain infectious throughout life $\mathrm{e}^{9-14}$.

The risk of this infection is correlated with the prevalence of infection of the assisted population and with the high frequency of exposure to blood and other fluids contaminated by HBV ${ }^{13}$. The probability of developing clinical HB is $22-31 \%$ and that of 
developing serologic evidence of infection is $37-62 \%$ when blood is positive for $\mathrm{HBs}(\mathrm{HBs}-\mathrm{Ag})$ and $\mathrm{Hbe}(\mathrm{HBe}-\mathrm{Ag})$ antigens. When blood is $\mathrm{HBs} \mathrm{Ag}$ positive and $\mathrm{HBeAg}$ negative, the probability of developing clinical $\mathrm{HB}$ is between 1 and $6 \%$ and the probability of developing serological evidence of $\mathrm{HBV}$ infection is $23-37 \%{ }^{14}$.

Professional serological evidence is essential to prevent occupational transmission of the disease. Some studies show that the serological test that determines Anti-Hbs, after HBV infection or vaccination, is the only way to verify the vaccine's effectiveness ${ }^{14-16}$.

In the last ten years, investigations related to vaccination for hepatitis $B$ have been related to dental professionals and other health professionals ${ }^{8-12,14-19}$. It must be taken into account that these workers are more exposed to communicable diseases and, therefore, they must be adequately immunized, in addition to having their immunity confirmed by performing the Anti-HBs test. Thus, the need is reinforced that, in addition to encouraging the completion of the complete vaccination schedule, efforts should also be made to perform the Anti-HBs test. Professionals and academics who have not developed an adequate level of antibodies should be encouraged to re-evaluate the formation of antibodies with a new exam.

Despite the importance of HBV vaccination and studies that have determined its prevalence among health professionals $^{1,2,5,6,9-11,14,19}$, there are few publications on vaccination and immunization among dental students in Brazil14,7,15,21.

It is believed that many dental students are not immunized because they have not completed the stages of vaccination and are not encouraged during graduation to restart the vaccination process.

According to this information, and the fact that Dentistry professionals are considered at risk for infection, because they are constantly exposed to blood samples in the work environment, 
testing in dental academics is essential, since it is possible to find them persons who are ill, unduly immunized, non-responding or non-seroconverted.

The objective of this research was to determine the previous prevalence of vaccination and immunity/ serum conversion and after vaccination against hepatitis B in dental academics.

\section{Material and method}

The present research was approved by the Research Ethics Committee of the State University of Piauí - CEP / UESPI, under the opinion 1.991.944, consisting of a prospective and experimental.

Included in the research were the dental academics who wish to participate in the research. Those who did not wish to participate were excluded. Initially the non-randomized sample should be of 117 students, corresponding to all students enrolled in the dentistry course, however 16 did not accept to participate (students who studied between the second and tenth period). Thus, the sample $(n=101)$ was composed of dental academics who were enrolled in 2017 ( $n=81$ ) and those who entered the first semester of $2018(n=20)$, since the admission of the students is only in the first semester of each year.

The research consisted of two stages: the first one (T1) with a self-administered questionnaire with epidemiological data with a vaccination card check and by applying the test to confirm the immunization. The second one (T2) corresponding to vaccination non-seroconverted and never vaccinated in addition to the immunity test.

Academics who were immunized at the beginning of the search, after application of the test for confirmation of immunization were called control group (CG). Students not previously vaccinated or not immunized and those who did not complete the three-dose vaccination schedule were called group $1(\mathrm{G} 1)$ and 
were encouraged to undergo a blood test to investigate the presence of HB in acute or chronic forms as well as confirmation of seroconversion after vaccination, without any burden on them. The costs associated with blood collection were the responsibility of the researchers responsible.

The criterion adopted was determined by the Ministry of Health when recommending that the vaccine should be administered in three doses (0, 1 and 6 months), and the complete vaccination schedule necessary for immunization. Thirty days after administration of the last dose of the HB vaccination schedule, members of the dental team checked if they had been effectively immunized by immunological exams ${ }^{9}$.

The certainty of immunization following the vaccination schedule is through the anti-HBs test, which should be performed one to six months after the last dose, indicated to verify the development of antibody protection levels. Immunity is acquired by the presence of the anti-HBs marker, being considered an adequate concentration, level above $10 \mathrm{mIU} / \mathrm{mL}^{12}$.

Ten $\mathrm{mL}$ of blood was collected by venipuncture using disposable syringes and needles. The serums were separated and stored in microtubes at $-20^{\circ} \mathrm{C}$ until the laboratory tests were performed ${ }^{12}$. Blood collection was done at the Family Health Strategy (FHS) position closest to the State University of Piauí during the school year, from July 2017 to July 2018.

Blood samples from all academics were tested for serological markers using commercial immunoenzymatic methodology kits, performed and interpreted: anti-HBs (anti-HBs kit IEMA WELL, RADIM ${ }^{\circledast}$ ), HBsAg (HBsAg ELISA kit, HUMAN ${ }^{\varpi}$ ) and total anti-HBc (ETI AB-AB COREK-2 kit, DIASORIN ${ }^{\circledR}$ ). HBsAg and total Anti-HBc markers were used in screening for the diagnosis of HB. The HBsAg antigen appears soon after the infection occurs, between 30 and 45 days. It can remain detectable for up to 120 days and is present in acute and chronic infections. 
The anti-HBc antigen indicates that the individual has been in contact with the virus and the positive result will remain throughout life, are cured or infected in a chronic way ${ }^{14}$.

The anti-HBs marker (antibodies against the HBV surface antigen) indicates immunity. It is generally detected within 1 to 10 weeks after the disappearance of HBsAg and indicates a good prognosis. When found alone, with all other negative markers, it indicates that the individual was vaccinated ${ }^{12-14}$.

If the $\mathrm{HBs} A g$ and Anti-HBc markers are positive, the patient is $\mathrm{HB}$. If only the Anti-HBc marker is positive, it indicates that the patient may be recovering, false positive or having chronic infection. If the Anti-HBc and Anti-HBs markers turn positive, it implies that the patient is recovering with immunity. If only the Anti-HBs marker is positive, it indicates immunization by vaccination ${ }^{12}$.

The pilot study involving 10 students aimed to test the proposed methodology. As a result, its viability was observed without adjustments. To measure inter- and intra-examiner diagnostic reproducibility, $10 \%$ of the total sample was double checked by each of the examiners, with the Kappa coefficient for intra and inter-examiner agreement of 0.97 and 0.98 , respectively.

The student presenting HBwould be referred to the Family Health Strategy (FHS) doctor closest to his home for immediate treatment, followed by the researchers. Vaccine cards were checked to identify how many doses of vaccine were taken by each participant, those who did not show the complete doses of the vaccine, were referred to restart the cycle in a Basic Health Unit (BHU) and those who had registered all the doses to the vaccine card were sent to the Serological Screening Center (SSC) in ParnaíbaPI to perform laboratory tests for immunity against hepatitis $B$.

Those who were not with $\mathrm{HB}$ or immunized were referred to the BHU to start the vaccination schedule. They were followed up by the researchers during the vaccination, and the vaccine cards were checked. 
The collected data were cataloged and submitted to statistical analysis, using the SPSS Program (version 21.0 Chicago III) through the technique of descriptive statistics, with absolute and percentage distributions. The results were presented in contingency tables.

Statistical significance was assessed using the chi-square test for the comparison of categorical exposure variables with outcome variables. For analysis purposes, the continuous variables were transformed into categorical variables. The level of significance of $\mathrm{p} \leq 0.05$ was adopted. For the coverage and prevalence estimates, the $95 \%$ confidence interval was used and for the inclusion of variables in the logistic regression model, a value of $\mathrm{p} \leq 0.05$ was used.

\section{Results}

Following the criteria of inclusion and exclusion of the research, 101 students from the Dentistry course of the State University of Piauí - UESPI participated in the study. Of these 46 (45.54\%) were male and 55 (54.45\%) were female. The age of the participants varied between 18 and 26 years (average of 21.5). Most were white $(57.8 \%)$, followed by brown (31.6\%) and black (8.4\%). Seventy-one students (70.3\%) entered the course due to wide competition and $30(29.7 \%)$ by quota system. Only 57 (56.43\%) academics presented a complete vaccination cycle before the beginning of the research, being 22 males and 35 females.

From the results, referring to the performance of descriptive statistics and inferential statistical tests of the chi-square, it was verified that 97 participants (96\%) were immunized against $\mathrm{HB}$, compared to $4(4 \%)$ that were not. This result was statistically significant $\left(\chi^{2}=85.63, \mathrm{p}<0.001\right)$.

Specifically, among those students with full cycle before the survey $(n=57)$, it was found after the anti-HBs test that most $(\mathrm{n}=56)$ were immunized, being such a statistically significant 
result, compared to a single participant who did not was immunized $\left(\chi^{2}=53.07, \mathrm{p}<0.001\right)$. Similar pattern was found with those who completed the vaccine cycle during the research. Of the 44 participants, 41 were immunized, being statistically significant compared to those who were not immunized $\left(\chi^{2}=32.82, \mathrm{p}\right.$ $<0.001$ ), (Table 1).

Regarding gender, when the vaccination cycle was observed before and after the research, 93.5\% $(n=43)$ of the male participants were immunized compared to the $6.5 \%(n=3)$ who were not of a total of 46 . This result was considered statistically significant $\left(\chi^{2}=34.78, \mathrm{p}<0.001\right)$. Regarding the female gender, a significant difference $\left(\chi^{2}=51.07, \mathrm{p}<0.001\right)$ was also observed, with $98.2 \%$ of the students immunized $(\mathrm{n}=54$ ) immunized out of a total of 55 . The four students who were not immunized re-started a new vaccine cycle (Table 1$)$.

In the binomial probabilistic analysis of the risk factors studied, increasing age (OR: 1.08; 95\% CI: 1.02-1.14), history of blood transfusion (OR: 6.41; 95\% CI: 1.53 6.83), increasing in the number of periods of clinical activity during the course (OR: 1.71; 95\% CI: 1.02-2.92), and history of accident with biological material (OR: 6.82; 95\% CI: 1.59 -7.15) were significantly associated with HBV infection in the studied population, according to Table 2.

\section{Discussion}

Immunization against $\mathrm{HB}$ is recognized as a high priority in all countries and strategies for immunization are under review. Universal vaccination of infants and adolescents is recommended, however, only 105 countries offer the free vaccine to all children. The difficulty of controlling infections in the dental environment puts the professionals and patients at risk and characterizes the primary need of this analysis ${ }^{15}$. 
TABLE 1 - Data on Immunization of students $(n=101)$ before and after research

\begin{tabular}{llllll}
\hline Variables & Male & Female & Total (\%) & $\mathbf{X}^{2}$ & p valor \\
\hline $\begin{array}{l}\text { Complete vaccination } \\
\text { prior to research (T1) }\end{array}$ & 22 & 35 & $57(56.4)$ & 53.7 & $0.01^{\star \star}$ \\
\hline $\begin{array}{l}\text { Immunized after } \\
\text { initial test (CG) }\end{array}$ & 21 & 35 & $56(55.4)$ & \\
\hline $\begin{array}{l}\text { Not immunized after } \\
\text { initial test (G1) }\end{array}$ & 1 & & $1(1)$ & \\
\hline $\begin{array}{l}\text { New vaccination stage } \\
\text { during research (T2) (G1) }\end{array}$ & 24 & 20 & $44(43.5)$ & 32.82 \\
\hline $\begin{array}{l}\text { Immunized after new } \\
\text { vaccination stage }\end{array}$ & 22 & 19 & $41(40.6)$ & \\
\hline $\begin{array}{l}\text { Not immunized after new } \\
\text { vaccination stage }\end{array}$ & 2 & 1 & $3(3)$ & \\
\hline
\end{tabular}

$X^{2}=$ Chi-square test; ${ }^{* *}$ significance with $1 \% ; * \star *$ significance $<1 \%$.

TABLE 2 - Binomial analysis of risk factors for exposure to the hepatitis B virus in exposed dental students

\begin{tabular}{|c|c|c|c|}
\hline Variables & $\%$ & Odds ratio (IC 95\%) & p valor \\
\hline \multicolumn{4}{|l|}{ Age ( years) } \\
\hline $17-19$ & 35 & $1.08(1.02-1.14)$ & $<0.01^{\star \star \star}$ \\
\hline $20-23$ & 50 & & \\
\hline$>24$ & 15 & & \\
\hline \multicolumn{4}{|l|}{ Blood transfusion } \\
\hline No & 94 & $6.41(1.53-6.83)$ & $0.01 \star \star$ \\
\hline Yes & 5 & & \\
\hline Sem informação & 2 & & \\
\hline \multicolumn{4}{|c|}{ Number of periods of clinical ativity } \\
\hline 1 & 15 & $1.71(1.02-2.92)$ & $0.02 *$ \\
\hline 2 to 4 & 30 & & \\
\hline$>4$ & 45 & & \\
\hline \multicolumn{4}{|c|}{ Accident with biological material } \\
\hline Yes & 80 & $6.82(1.59-7.15)$ & $0.01 \star \star$ \\
\hline No & 21 & & \\
\hline
\end{tabular}

Odds ratio: Estimated by binomial logistic regression; IC: Confidence interval; * significance with 5\%; **significance with $1 \%$; $* \star *$ significance $<1 \%$. 
According to these data, it was evidenced that a significant number of students had not started the vaccination cycle and were unaware of the importance of immunization. The prevalence of dental students who were vaccinated against $\mathrm{HB}$ was $56.4 \%$, being considered low, as shown in Table1, corroborating the findings of Carneiro et al. ${ }^{21}(2009)$, whose vaccination rate was also not satisfatory (48.25\%).

Fourty-four students need to start the three-dose vaccination cycle, which is worrisome because 90 were already having clinical activities and 80 had already had an accident at least once with biological material and 5 had already had a blood transfusion. Beyound the higher the age, the greather the level of virus exposure (Table 2). It is worth mentioning that dental students and professionals are among health professionals with high exposure to the risk of HBV infection due to the type of procedures performed and the frequency of exposure to biological materials ${ }^{22,23}$.

Accidents are more frequent in dentistry students, possibly because they are still in the process of learning, and consequently have little skill and ability in the handling of materials. Therefore, immunizations reduce the risk of infections and, consequently, protect not only the health of the components of the dental team, such as those of their patients and their families ${ }^{16,17}$.

The vaccine provides immunity to dental academics who are often exposed to blood and other body fluids, provided adherence to the recommended number of doses is achieved, although proof of immunity is required. Of the four academics who were not immunized, 3 are male. Although similar results have been reported previously, 19 in which women had a higher level of anti-HBs, gender differences were not considered relevant even when vaccination programs were developed ${ }^{20}$. These data corroborate another study carried out by Souza et al. ${ }^{11}$ (1994), which found that $80 \%$ of all dental surgeons demonstrated adequate response to the vaccine, most of them women. 
The first vaccines created originated from the purified blood plasma of people with asymptomatic $\mathrm{HB}$, establishing doubts and insecurities about the effectiveness, size of the side effects and HIV infection. However, today, with genetic and technological developments, vaccines are produced in greater contingencies, being safer and immunogenic ${ }^{22}$.

Tada et al. ${ }^{23}$ (2014) stated that it is an effective vaccine (90 to 95\% of vaccine responses in immunocompetent adults) and safe. The study by Silva et al. ${ }^{20}$ found that the adequate antibody response to the HBV vaccine occurs in more than $90 \%$ of all healthy adults completing the recommended three-dose series.

Regarding laboratory tests, the results showed that $96 \%$ were immunized. Other studies ${ }^{1,12,18}$ have observed similar results emphasizing that post-vaccinal serological non-testing may give the false safety of protection conferred by immunization because, despite the high efficacy of the HB vaccine, about 5 to $10 \%$ are not immunized, revaccination is required with a second series of 3 doses.

It is known that there are factors that predispose to the failure of the immune response, such as genetic factors, site of vaccine application, concomitance with other diseases, storage conditions and vaccine handling. Therefore, the seroconversion test is necessary to verify the efficacy of the vaccination schedule, preventing the risks of virus contamination ${ }^{18-24}$.

Although this study was conducted among dentistry students from a single state university, not representing all universities in the region, the data obtained is important for the elaboration and intensification of effective strategies for the design of actions aimed at the prevention and control of HBV infection in these future professionals. 


\section{Conclusion}

It was concluded that the prevalence of seroconversion was $96.03 \%$, corresponding to 97 immunized students.

Although all dental academics completed the vaccination cycle (3 doses), 4 were not immunized. The limitation was $(n=16)$ students who did not wish to participate in the research.

Vaccination and the need for serological testing (anti-HBs) for immunization verification should be encouraged to all dental academics.

It is suggested to include the presentation of the vaccination card and the result of the serological test (anti-HBs) as mandatory documents for access to undergraduate courses in Dentistry.

\section{References}

1 - Souza FO, Freitas PSP, Araújo TM, Gomes MR. Vacinação contra hepatite B e anti-HBS entre trabalhadores da saúde. Cad Saúde Colet. 2015; 23(2): 172-9.

2 - Momeni N, Ahmad Akhoundi MSA, Alavian SM, Shamshiri AR, Norouzi M, Mahboobi N, Moosavi N, Jazayeri SM. HBV Vaccination status and response to hepatitis b vaccine among iranian dentists, correlation with risk factors and preventive measures. Hepat Mon. 2015; 15(1): e2014.

3 - Ferreira LQ, Oschiro AC, Cruz MCC, Camargo RP, Cruz MC. Hepatitis B: knowledge and attitudes of dentistry students. Arch Health Invest. 2018; 7(7): 258-61.

4 - Takemoto MM, Werlang FA, Zasso FM, Tomazelli KB, Giusti FM. Perfil de imunização contra hepatite B dos alunos do curso de odontologia da UCEFF. Rev. Tecnológica. 2017; 6(1): 1-6.

5 - Costa FM, Martins AMEBL, Lima CA, Rodrigues QF, Santos KKF, Ferreira RC. Fatores associados com a verificação de imunização pósvacinal contra hepatite B entre profissionais de atenção primária. Cad Saúde Colet. 2017; 25(2):192-200.

6 - Milfon JAC, Oliveira AHA. Equipamentos de proteção individual em odontologia: revisão integrative de literature. Rev Interf Saúde Humanas e Tecnologia. 2015; 3(8): 01-06.

7 - Teixeira SO, Tobias KR, Aleixo RQ, Dias AGA, Galvão NS. Hepatitis B: Knowledge and vaccination coverage of dental students in college São Lucas. Clipe Odonto. 2016; 8(2): 26-35. 
8 - Abich DR, Lima GCS, Lissarassa YPS, Mallet EKV, Comparsi B. Immunização contra o vírus de hepatitis B em estudantes de saúde. Contexto \& Saúde. 2016; 16(30): 77-84.

9- Martins AMEBL, Costa FM, Ferreira RC, Santos Neto PE, Magalhães TA, Sá AB, Pordeus IA. Factors associated with immunization against Hepatitis B among workers of the Family Health Strategy Program. Rev Bras Enferm. 2015; 68(1): 84-92.

10 - Assunção AA, Araújo TM, Ribeiro RBN, Oliveira SVS. Hepatitis B vaccination and occupation exposure in the healthcare sector in Belo Horizonte, Southeastern Brazil. Rev Saúde Pública. 2012; 46(4): 665-73.

11 - Souza EP, Teixeira MS. Hepatitis B vaccination coverage and post vaccination serologic testing among medical students at a publica university in Brazil. Rev Inst Med Trop. 2014; 56(4): 307-11.

12 - Arantes DC, Nascimento LS, Hage CA, Pontes FSC. Biossegurança aplicada a odontologia da Universidade Federal do Pará, na cidade de Belém, estado do Pará, Brazil. Rev Pan Amaz Saúde. 2015; 6(1): 11-18.

13 - Lages SMR, Santos AF, Silva Junior FF, Costa JG. Formação em odontologia: o papel das instituições de ensino na prevenção do acidente com exposição a material biológico. Ciência e trabajo. 2015; 17(54): 182-187.

14 - Silva BASS, Carvalho WM, Falcão CAM, Leite CMC, Monte TL, Ferraz MAAL. Adesão à vacina contra hepatite B entre cirurgiões dentistas. Rev Interd. 2016; 9(4): 114-21. .

15 - Silva FAG, Guedes EA, Miasato JM. Prevalência da vacinação contra hepatite B de graduandos em odontologia da UNIFESO/RJ. Arquivos em Odontologia. 2009; 45(3): 117-21.

16 - Fernandes CNS, Alves MM, Souza ML, Machado GA, Couto G, Evangelista RA. Prevalence of seropositivity for hepatitis B and C in pregnant. Rev Esc Enferm USP. 2014; 48(1): 91-8.

17 - Haridi HK, Al-Ammar AS, Al-Mansour MI. Compliance with infection control standard precautions guidelines: a survey among dental healthcare workers in Hail Region, Saudi Arabia. Journal of Infection Prevention. 2016; 17(6): 268-276.

18 - Garbin AJI, Wakayama B, Garbin CAS. Negligence in health self-care: immunization against hepatitis B in Dentistry. Arch Health Invest. 2016; 5(2): 85-89.

19 - Martins RJ, Moimaz SAS, Sundefeld, MLMM, Garbin, AJI, Gonçalves PRV, Garbin CAS. Adesão às precauções padrão sob o prisma do modelo de crenças em saúde: a prática de reencapar agulhas. Cienc Saúde Colet. 2015; 20(1): 193-8.

20 - Silva Junior MF, Assis RIF, Gomes CLR, Miclos PV, Sousa HA, Gomes MJ. Conhecimento atual sobre a necessidade de imunização da hepatite B dos acadêmicos da área da saúde de uma universidade brasileira. Arq Odontol. 2014; 50(3): 131-137. 
21 - Carneiro GGVS, Cangussu MCT. Prevalência presumível, cobertura vacinal, conhecimentos e atitudes relativos à hepatite $\mathrm{B}$ em graduandos de Odontologia da Universidade Federal da Bahia. Rev Odont Unesp. 2009; 38(1): 7-13.

22 - Wu L, Yin Y-L, Song J-L, Chen Y, Wu Y-F, Zhao L. Knowledge, attitudes and practices surrounding occupational blood-borne pathogen exposure amongst students in two Chinese dental schools. Eur J Dent Educ. 2016; 20(4): 206-12.

23 - Tada A, Watanabe M, Senpuku H. Factors influencing compliance with infection control practice in Japanese dentists. International Journal of Occupational and Environmental Medicine. 2014; 5(1): 24-31.

24 - Garbin CAS, Wakayama B, Saliba TA, Saliba Jr OA, Garbin AJI. A cross-sectional study on dental surgeons' immune status against hepatitis B virus in the Public Health System. Rev Inst Med Trop de São Paulo. 2020; 62: e18. 


\title{
Vacinação e imunização de hepatite B em estudantes de odontologia
}

\begin{abstract}
Resumo
Objetivo: determinar a prevalência prévia de vacinação e imunidade / conversão sérica após vacinação contra hepatite $B$ em acadêmicos de odontologia. Material e Métodos: foi realizado um estudo com 101 alunos de graduação em odontologia matriculados em 2017 e no primeiro semestre de 2018. A pesquisa teve duas etapas: a primeira (T1) com questionário autoaplicável com dados epidemiológicos, checagem do cartão de vacinação e aplicação de teste para confirmação da imunização. A segunda (T2) corresponde à vacinação não soroconvertida e nunca vacinada, além do teste de imunidade. Resultados: a idade dos participantes variou entre 18 e 26 anos (média de $21,5)$. A maioria era branca $(57,8 \%)$, seguida da parda $(31,6 \%)$ e negra $(8,4 \%)$. Setenta e um alunos $(70,3 \%)$ ingressaram no curso por ampla competição e $30(29,7 \%)$ por sistema de cotas. Verificou-se que 97 participantes $(96 \%)$ estavam imunizados contra HB, contra $4(4 \%)$ que não estavam. Este resultado foi estatisticamente significativo $\left(\chi^{2}=85,63, p<0,001\right)$. Na análise probabilística binomial dos fatores de risco estudados, aumento da idade (OR: 1,08; IC 95\%: 1,02-1,14), história de hemotransfusão (OR: 6,41; IC 95\%: 1,53 6,83), aumento no número de períodos de atividade clínica durante o curso (OR: 1,71; IC 95\%: 1,02-2,92) e história de acidente com material biológico (OR: 6,82; IC 95\%: 1,59-7,15) foram significativamente associados à infecção pelo VHB na população estudada. Conclusão: A prevalência de soroconversão foi de $96,03 \%$, correspondendo a 97 alunos imunizados. Embora todos os acadêmicos de odontologia tenham completado o ciclo de vacinação (3 doses), 4 não foram imunizados. A vacinação e a necessidade de teste sorológico (anti-HBs) para verificação da imunização devem ser incentivadas a todos os estudantes de odontologia.
\end{abstract}

PALAVRAS-CHAVE: Hepatite B. Imunização. Vacinação.

\section{How to cite this paper}

Lira ALS; Martins KRJ. Hepatitis B vaccination and immunization of dental students. Rev Odontol Bras Central 2021; 30(89): 180-194. DOI: 10.36065/robrac.v30i89.1445 